\author{
mgr Anna KURZAK-MABROUK \\ Wydział Zarządzania, Politechnika Częstochowska \\ e-mail: anna.magister@gmail.com
}

DOI: $10.15290 /$ ose.2017.04.88.14

\title{
SPÓJNOŚĆ DZIAłAŃ W OBSZARZE ZRÓWNOWAŻONEGO ROZWOJU W BRANŻY SPOŻYWCZEJ
}

\begin{abstract}
Streszczenie
Zrównoważony rozwój jest koncepcją wypracowaną w drodze wieloletnich negocjacji i prac na arenie międzynarodowej, której głównym celem jest poprawa jakości życia społeczeństw w czystym środowisku naturalnym. Skupia ona w sobie trzy aspekty, tj.: ekologiczny, społeczny i ekonomiczny, a realizowanie działań w wymienionych trzech obszarach zmierza do osiagnięcia efektywnego rozwoju. W artykule zaprezentowano teoretyczne podstawy koncepcji zrównoważonego rozwoju i branży spożywczej w odniesieniu do polskiej gospodarki oraz działania, jakie powinny podejmować wszystkie przedsiębiorstwa spożywcze, aby przedstawiana koncepcja była skuteczna. Celem pracy jest wskazanie, iż w przedsiębiorstwach przemysłu spożywczego korzystne jest realizowanie działań wspierających zrównoważony rozwój, a także jak te działania wygląajaj.

Wykorzystane w artykule metody badań polegają na analizie danych zastanych. Analizie zostały poddane istniejące już dane wtórne, wcześniej zgromadzone i przetworzone przez instytucje publiczne, co jest metodą deskresearch. Ponadto, zastosowano jednocześnie analizę treści i pisemnych komunikatów tekstowych. Część artykułu, na którą składa się przegląd działań, jakie powinno się realizować w przedsiębiorstwach przemysłu spożywczego, powstała w wyniku gruntownej analizy literatury dotyczącej: zrównoważonego wznoszenia budynków, zrównoważonego personelu, zrównoważonego zarządzania, ekologicznych innowacji produktowych, opakowaniowych i technologicznych, zrównoważonej produkcji i utylizacji odpadów opakowaniowych. W części badawczej artykułu wyjaśniono, w jaki sposób przedsiębiorstwa przemysłu spożywczego powinny realizować swoją działalność, by była ona zgodna z zasadami zrównoważonego rozwoju. Dzięki temu możliwe jest poznanie odpowiedzi na podane pytania badawcze. Czy przemysł spożywczy ma duży wpływ na powstawanie produktów opakowaniowych? Jaki powinien być zrównoważony produkt, co go cechuje i jak go projektować? Jacy powinni być pracownicy zatrudnieni w przedsiębiorstwach charakteryzujących się cechami zrównoważenia, jak również czym wyróżniają się współpracownicy i dostawcy. W jaki sposób powinna być realizowana produkcja, aby w jak najmniejszym stopniu negatywnie oddziaływać na człowieka i przyrodę? Które surowce i w jaki sposób oszczędzać, żeby nie doprowadzić do ich całkowitego zużycia?
\end{abstract}

Słowa kluczowe: zrównoważony rozwój, branża spożywcza, przedsiębiorstwo, konsument

\section{SUSTAINABLE DEVELOPMENT IN FOOD INDUSTRY: COHERENCE OF ACTION}

\section{Summary}

Sustainable development is a concept developed after years of negotiations and disputes on the international stage. Its main goal is to improve the quality of life of societies in a clean environment. It focuses on three aspects: ecological, social, and economic. It is imperative to carry out the activities in 
these three areas so that all the problems important for building a long-term business strategy are addressed. This will make it possible to achieve effective development. In this paper, the author presents the theoretical foundations of the concept of sustainable development in the food industry in relation to the Polish economy and the actions that all food businesses should take in order for the presented concept to be effective. The purpose of the work is to show why businesses in the food industry are benefiting from actions that promote sustainable development and how they behave.

The research methods used involve analysis of available data. The existing secondary data previously collected and processed by public institutions are analyzed (a desk research method). In addition, content analysis is conducted, where written messages are examined. The paper, which includes an overview of activities recommended for food industry companies, was developed through a thorough literary analysis of sustainable building, sustainable staffing, sustainable management, innovations regarding ecological products, packaging and technologies, sustainable production and disposal of packaging waste. The research section explains how food business operators should implement their activities to ensure that they are sustainable. Thanks to this, it is possible to find the answers to the following research questions: Does the food industry have a major impact on the formation of packaging products? What should the sustainable product be, what characterizes it and how to design it? What should employees working for sustainable companies be like? What should be the characteristics of the collaborators and suppliers of a sustainable company? How should production be implemented so as to have a minimal negative impact on people and the natural environment? Which raw materials to save, and how to do it so as not to exhaust them completely?

Key words: sustainable development, food industry, enterprise, consumer

JEL classification: O, D23, L66, Q01

\section{Wstęp}

Przyrost przedsiębiorstw produkcyjnych nastapił od połowy XX wieku. Ekspansja przemysłu przyczyniła się do tego, iż w środowisku naturalnym zaczęło pojawiać się wiele negatywnych zmian. We współczesnej epoce geologicznej, którą nazywa się antropocenem, nastąpiły zmiany klimatyczne, oceany uległy zakwaszeniu, a biomy ${ }^{1}$ zaczęły zanikać tak szybko, że możliwe stało się zmierzenie tego w czasie życia jednego pokolenia. Przyspieszone tempo oraz kierunek tych zmian skłania do refleksji, iż Ziemia z roku na rok może stać się coraz mniej przyjazna dla społeczeństw [Richardson $i$ in. 2011]. Spośród negatywnych ludzkich zachowań należy ocenić te, które stanowią największe zagrożenie dla wytrzymałości planety [Rockströmi in. 2009]. Taki przebieg rozwoju pozwala na sformułowanie tej konkluzji, iż przyszłość wielu organizmów staje się niepewna. Różnorodność biologiczna oceniona za pomoca wskaźnika The Living Planet Index, na podstawie 14152 monitorowanych populacji 3706 gatunków kręgowców, daje powody do niepokoju, gdyż wykazuje tendencję spadkową. Pomiędzy 1970 a 2012 rokiem miał miejsce spadek liczebności populacji monitorowanych gatunków, średnio o około $58 \%$, przy czym bardziej był zauważalny spadek gatunków słodkowodnych. Natomiast za pomocą Ecological Footprint Index, który mierzy ślad ekologiczny, można zauważyć relację między możliwościami Ziemi a ludzkim postępowaniem. Wskaźnik ten ukazuje ludzkie zapotrzebowanie na oferowany przez Ziemię dostęp do zasobów odnawialnych i usług ekologicznych [National Footprint Accounts, 2016]. Liczne zagrożenia ekologiczne

1 Biom - rozległy obszar o określonym klimacie, charakterystycznej szacie roślinnej i szczególnym świecie zwierzęcym. 
i społeczne, jakie zaczęły występować na świecie, spowodowały podjęcie globalnych działań w celu im zapobieżenia, to natomiast przyczyniło się do wypracowania założeń koncepcji zrównoważonego rozwoju.

\section{Wyłonienie się zrównoważonego rozwoju i jego progres}

Przez lata, podczas licznych działań na arenie globalnej, zostało wypracowanych bardzo wiele definicji zrównoważonego rozwoju. Prawie dwuletnia współpraca komisji z Brundtland [Our Common Future, 1987] zaowocowała wyłonieniem się jednej z pierwszych, która stwierdziła, iż zrównoważony rozwój daje możliwość zaspokajania bieżących oczekiwań społeczeństw bez obawy, że potrzeby kolejnych pokoleń nie zostaną zrealizowane [Brzustewicz, 2013, s. 8]. Ciagłość prac nad koncepcją zrównoważonego rozwoju zapewniały Konferencje Narodów Zjednoczonych poświęcone problemom: środowiska, człowieka i zrównoważonego rozwoju, które odbyły się w 1972 roku w Sztokholmie, podczas tzw. II Szçytu Ziemi mającego miejsce w 1992 roku w Rio de Janeiro [Kowalczyk, 2010], gdzie powstała „Agenda 21” [Agenda 21 w Polsce, 1997], w 2002 roku w Johannesburgu i ponownie w Rio de Janeiro w 2012 roku. Częściej odbywaja się konferencje stron porozumienia w sprawie konwencji klimatycznej, a ze względu na przyjęte rozwiązania najbardziej nagłośniono te z Kioto, gdzie przyjęto dokument Protokót z. Kioto do ramowej Konwencji Narodów Zjednoczonych w sprawie zmian klimatu [Protokót z Kioto..., 1997] i Hagi (2000)[Kurzak, 2014] oraz z Paryża w 2015 roku w. Jedna z nich również miała miejsce w Polsce, w Poznaniu w 2013 roku. W myśl zasady sprawiedliwości wewnątrzpokoleniowej i międzypokoleniowej, dzięki zrównoważonemu rozwojowi dąży się do zapewnienia współczesnym, jak również przyszłym pokoleniom standardów ekologicznych, społeczno-kulturowych i ekonomicznych na wysokim poziomie, aby nie zostały przekroczone naturalne granice wytrzymałości planety [Rogall, 2010, s. 37]. Pośród wielu definicji pojawiają się elementy spójne, takie jak rozwój społeczno-gospodarczy, który integruje działania społeczeństw zmierzające do najskuteczniejszego wyrównania możliwości następnych pokoleń do życia w czystym środowisku naturalnym [Korol, 2007, s. 48]. Zrównoważony rozwój jest koncepcją, mająca równoważyć swoje trzy podstawowe cele w jednakowym stopniu [Adamczyk, 2001, s. 135]. Rozwiązanie największych globalnych problemów współczesnych czasów jest niezbędne, by zmienić świat [Marketing 3.0, 2010]. Aby osiagnąć zrównoważony rozwój, konieczne jest wystapienie spójności triady jego celów: wzrostu gospodarczego, ochrony środowiska i inkluzji społecznej. Elementy te są nierozerwalne i równie ważne, żeby w równej mierze poszczególne jednostki, jak i całe społeczeństwa osiagnęły dobrobyt w czystym środowisku naturalnym.

Zrównoważony rozwój to koncepcja powstała w konsekwencji globalnego kryzysu gospodarczego, z którym połączona jest konieczność dopasowywania się do, zachodzacych w niepewnym otoczeniu, permanentnych, trudnych do przewidzenia zmian $\mathrm{w}$ warunkach chaosu. Warunki te kształtuja niełatwe do zaplanowania zmiany ekonomiczne, społeczne i polityczne [Sustainability w biznnesie..., 2010, s. 300]. Można zatem wnioskować, iż zrównoważony rozwój powstał w następstwie stale pogarszającego się stanu środowiska przyrodniczego i pojawiających się zagrożeń w funkcjonowaniu 
społeczeństw [Pabian, 2013, s. 12]. Spowodowanie przywrócenia równowagi lub nienaruszanie jej jest wynikiem dostosowania się do założeń zrównoważonego rozwoju. Przedsiębiorstwom zależy na tym, aby stały się konkurencyjne, stąd nieodzowne jest respektowanie potrzeb społeczeństwa, co stanowi integralną część tworzenia wartości ekonomicznej [Porter, Kramer, 2011, s. 15].

\section{Znaczenie przedsiębiorstw przemysłu spożywczego dla polskiej gospodarki}

Stosowanie się do zasad zrównoważonego rozwoju przez przedsiębiorstwa produkcyjne branży spożywczej znaczy, iż wprowadzają one do swej działalności innowacje technologiczne i produktowe, które są korzystniejszymi rozwiązaniami dla społeczeństw i środowiska naturalnego.

Sektor spożywczy obejmuje: producentów artykułów spożywczych ${ }^{2}$ skierowanych do ludzi i zwierząt, producentów napojów, w tym napojów alkoholowych ${ }^{3}$ i producentów wyrobów tytoniowych ${ }^{4}$. Do sektora spożywczego nie zalicza się: producentów płodów rolnych, hodowców zwierząt oraz tych, którzy zajmują się rybactwem i rybołówstwem ${ }^{5}$, przedsiębiorców dystrybuujących żywnośćc ${ }^{6}$ jak również przygotowujących posiłki do bezpośredniego spożycia ${ }^{7}$.

Przemysł spożywczy to dział gospodarki zajmujący się wytwarzaniem produktów oraz półproduktów przeznaczonych do spożycia, do którego zalicza się: mleczarnie, zakłady przetwórstwa mięsnego i rybnego, cukrownie, piekarnie, przetwórnie owocowo-warzywne, wytwórnie soków, zakłady tytoniowe, gorzelnie, młyny, browary. Produkty spożywcze klasyfikuje się według kryterium trwałości, w stosunku do którego wyodrębnia się artykuły trwałe i nietrwałe.

Konsumenci, nabywający artykuły spożywcze, jako głównym kryterium kierują się specyficznymi dla danego produktu walorami smakowymi. Równie istotny podczas procesu zakupowego jest skład produktu, aby było w nim zawartych jak najmniej szkodliwych substancji, takich jak: konserwanty, barwniki, spulchniacze oraz składniki poprawiające smak i zapach. Konsumenci równie dużą wagę przywiązują do daty przydatności produktów do spożycia (daty ważności produktu). W Unii Europejskiej kwestię trwałości produktów spożywczych reguluje Dyrektywa 200/13/WE Parlamentu Europejskiego $i$ Rady, z późniejszymi zmianami, a w Polsce kwestię terminu przydatności do spożycia produktów spożywczych reguluje Ustawa o bespieczeństwie ṡymności.

Produkcja sprzedana przemysłu jest głównym miernikiem działalności gospodarczej. Wartość ta jest wyrażona w cenach bazowych, bez uwzględnienia podatku VAT (od towarów i usług) i akcyzowego, lecz wraz z wartością otrzymanych dotacji przedmiotowych, tj. dotacji do produktów (wyrobów i usług). Zawiera się w niej całokształt

\footnotetext{
Sekcja C Polskiej Klasyfikacji Działalności, dział 10.

Sekcja C Polskiej Klasyfikacji Działalności, dział 11.

Sekcja C Polskiej Klasyfikacji Działalności, dział 12.

Sekcja A Polskiej Klasyfikacji Działalności.

Sekcja G Polskiej Klasyfikacji Działalności, dział 46 - handel hurtowy.

Sekcja I PKD, dział 56 - działalność usługowa związana z wyżywieniem.
} 
działalności podmiotów gospodarczych, łącznie z działalnością przemysłową i nieprzemysłową. Jej wartość obejmuje:

- $\quad$ wartość produktów sprzedanych na zewnątrz przedsiębiorstwa, bez uwzględnienia faktu, czy otrzymano za nie należyte profity;

- $\quad$ wartość produktów wytworzonych, niezaliczonych do sprzedaży, lecz na równi $\mathrm{z}$ nią traktowanych;

- $\quad$ zryczałtowaną odpłatność agenta należną mu za powierzone prowadzenie działalności gospodarczej itp., na podstawie umowy (zlecenia) zawartej z agentem.

TABELA 1.

Liczba podmiotów gospodarczych prowadzących działalność gospodarczą w 2014 roku i wielkość produkcji sprzedanej przemysłu, według sekcji i działów w 2014 roku, w cenach bieżących (w mln zł)

\begin{tabular}{|c|c|c|}
\hline Wyszczególnienie & $\begin{array}{c}\text { Podmioty } \\
\text { gospodarcze }\end{array}$ & $\begin{array}{l}\text { Produkcja } \\
\text { sprzedana }\end{array}$ \\
\hline Ogółem & 200025 & 1166591,0 \\
\hline Górnictwo i wydobywanie & 1931 & 47301,5 \\
\hline Przetwórstwo przemysłowe, w tym: & 187520 & 995888,2 \\
\hline produkcja artykułów spożywczych & 14142 & 187777,8 \\
\hline produkcja napojów & 483 & 19860,5 \\
\hline produkcja wyrobów tytoniowych & 33 & 4331,9 \\
\hline produkcja wyrobów tekstylnych & 5072 & 9961,2 \\
\hline produkcja odzieży & 12908 & 6976,6 \\
\hline produkcja skór i wyrobów skórzanych & 3222 & 4208,8 \\
\hline produkcja wyrobów z: drewna, korka, słomy i wikliny & 17039 & 30176,1 \\
\hline produkcja papieru i wyrobów z papieru & 3067 & 33545,4 \\
\hline poligrafia i reprodukcja zapisanych nośników informacji & 8796 & 10836,8 \\
\hline produkcja koksu i produktów rafinacji ropy naftowej & 165 & 80265,6 \\
\hline produkcja chemikaliów i wyrobów chemicznych & 2312 & 54479,2 \\
\hline produkcja wyrobów farmaceutycznych & 343 & 12335,5 \\
\hline produkcja wyrobów z gumy i tworzyw sztucznych & 8311 & 70165,7 \\
\hline produkcja wyrobów z pozostałych mineralnych surowców niemetalicznych & 9076 & 44522,0 \\
\hline produkcja metali & 1310 & 44218,9 \\
\hline produkcja wyrobów z metali & 32141 & 73732,7 \\
\hline produkcja: komputerów, wyrobów elektronicznych i optycznych & 3182 & 33741,1 \\
\hline produkcja urządzeń elektrycznych & 2258 & 47315,1 \\
\hline produkcja maszyn i urządzeń & 4813 & 37237,0 \\
\hline produkcja: pojazdów samochodowych, przyczep i naczep & 1414 & 113154,1 \\
\hline produkcja pozostałego sprzętu transportowego & 1467 & 15706,9 \\
\hline produkcja mebli & 15321 & 32402,6 \\
\hline pozostała produkcja wyrobów & 14078 & 7784,3 \\
\hline naprawa, konserwacja i instalowanie maszyn i urządzeń & 26567 & 21152,3 \\
\hline $\begin{array}{l}\text { Wytwarzanie, zaopatrywanie w: energię elektryczna, gaz, parę wodną i gorąca } \\
\text { wodę }\end{array}$ & 2588 & 96594,2 \\
\hline Dostawa wody, gospodarowanie ściekami i odpadami, rekultywacja, w tym: & 7986 & 26807,2 \\
\hline pobór, uzdatnianie i dostarczanie wody & 1207 & 6314,5 \\
\hline gospodarka odpadami, odzysk surowców & 4311 & 12996,7 \\
\hline
\end{tabular}

Źródło: opracowanie własne na podstawie danych GUS: [http://stat.gov.pl/]. 
Zaprezentowane dane ukazują wielkość przemysłu spożywczego na arenie polskiej gospodarki. W Polsce liczba podmiotów gospodarczych działających w sektorze spożywczym wynosiła 14 658, obejmując prawie 8\% całego przetwórstwa przemysłowego, plasując ten sektor na 5. miejscu. Natomiast produkcja sprzedana przetwórstwa przemysłowego osiąnęła 995 888,2 mln zł, przemysłu spożywczego 211 970,2 mln zł, co równa się 30\% całego przetwórstwa przemysłowego. Produkcja sprzedana artykułów spożywczych stanowi znaczną ilość produkcji sprzedanej przetwórstwa przemysłowego. Popyt ten uzmysławia, iż niezbędne jest wprowadzanie zasad zrównoważonego rozwoju w przedsiębiorstwach przemysłu spożywczego, aby działalność produkcyjna tych przedsiębiorstw mogła przyczyniać się do poprawy jakości życia obecnych i przyszłych pokoleń w czystym środowisku naturalnym.

TABELA 2.

\section{Przychody z całokształtu działalności podmiotów gospodarczych, według sekcji i działów, w 2014 roku ogółem (w mln zł)}

\begin{tabular}{|c|c|c|c|}
\hline \multicolumn{2}{|l|}{ Wyszczególnienie } & \multicolumn{2}{|c|}{$\begin{array}{l}\text { W tym przychody netto ze } \\
\text { sprzedaży }\end{array}$} \\
\hline & & $\begin{array}{l}\text { produktów } \\
\text { (wyrobów } \\
\text { i usług) }\end{array}$ & $\begin{array}{l}\text { towarów } \\
\text { i materiałów }\end{array}$ \\
\hline Ogółem & 1402685,9 & 1099534,1 & 251435,7 \\
\hline Górnictwo i wydobywanie & 56284,8 & 46370,8 & 4440,6 \\
\hline Przetwórstwo przemysłowe, w tym: & 1114687,9 & 928774,6 & 161736,9 \\
\hline produkcja artykułów spożywczych & 190872,8 & 156681,4 & 29922,6 \\
\hline produkcja napojów & 31606,7 & 27332,0 & 3389,4 \\
\hline produkcja wyrobów tytoniowych & 11715,4 & 7164,2 & 4496,2 \\
\hline produkcja wyrobów tekstylnych & 9562,0 & 8525,7 & 817,6 \\
\hline produkcja odzieży & 4818,9 & 3888,9 & 726,7 \\
\hline produkcja skór i wyrobów skórzanych & 3785,6 & 3285,0 & 409,2 \\
\hline produkcja wyrobów z: drewna, korka, słomy i wikliny & 26984,0 & 23994,9 & 2539,0 \\
\hline produkcja papieru i wyrobów z papieru & 33147,0 & 30556,9 & 1863,9 \\
\hline poligrafia i reprodukcja zapisanych nośników informacji & 10573,7 & 9377,9 & 886,6 \\
\hline produkcja koksu i produktów rafinacji ropy naftowej & 139095,1 & 88456,8 & 48351,6 \\
\hline produkcja chemikaliów i wyrobów chemicznych & 62167,4 & 52393,0 & 8119,0 \\
\hline produkcja wyrobów farmaceutycznych & 15659,2 & 11793,5 & 3223,5 \\
\hline produkcja wyrobów z gumy i tworzyw sztucznych & 71984,3 & 63990,6 & 6391,2 \\
\hline $\begin{array}{l}\text { produkcja wyrobów z pozostałych mineralnych surowców } \\
\text { niemetalicznych }\end{array}$ & 45772,3 & 39727,5 & 4809,9 \\
\hline produkcja metali & 46349,9 & 42484,8 & 2873,0 \\
\hline produkcja wyrobów z metali & 74619,0 & 64587,6 & 8110,0 \\
\hline produkcja: komputerów, wyrobów elektronicznych i optycznych & 37339,1 & 32485,8 & 4037,5 \\
\hline produkcja urządzeń elektrycznych & 53613,0 & 45095,6 & 7724,9 \\
\hline produkcja maszyn i urządzeń & 40592,2 & 34383,9 & 5096,8 \\
\hline produkcja: pojazdów samochodowych, przyczep i naczep & 122293,1 & 111504,8 & 8862,5 \\
\hline produkcja pozostałego sprzętu transportowego & 17454,5 & 14968,9 & 1889,2 \\
\hline produkcja mebli & 32080,9 & 28672,0 & 2861,6 \\
\hline pozostała produkcja wyrobów & 9125,4 & 6788,3 & 2092,1 \\
\hline naprawa, konserwacja i instalowanie maszyn i urządzeń & 23476,4 & 20634,6 & 2242,9 \\
\hline $\begin{array}{l}\text { Wytwarzanie i zaopatrywanie w: energię elektryczna, gaz, } \\
\text { parę wodną i gorącą wodę }\end{array}$ & 199924,5 & 98781,1 & 80759,4 \\
\hline $\begin{array}{l}\text { Dostawa wody, gospodarowanie ściekami i odpadami, rekulty- } \\
\text { wacja }\end{array}$ & 31788,7 & 25607,6 & 4498,8 \\
\hline
\end{tabular}

Źródło: opracowanie własne na podstawie danych GUS: [http://stat.gov.pl/]. 
Przychód z całokształtu działalności (kwoty otrzymane i należne) jest ustalony w wartości wyrażonej w rzeczywistych cenach sprzedaży, uwzględniając: rabaty, upusty, bonifikaty i bez podatku VAT (od towarów i usług). Zawierają się w nim:

- $\quad$ przychody netto ze sprzedaży: produktów, wyrobów i usług;

- $\quad$ przychody netto ze sprzedaży towarów i materiałów, łącznie z kwotami należnymi z tytułu sprzedaży opakowań wielokrotnego użytku;

- pozostałe koszty operacyjne, niezwiązane bezpośrednio z główną działalnością podmiotu;

- $\quad$ przychody finansowe $z$ tytułu operacji finansowych wykonanych przez podmiot.

W 2014 roku największy przychód z całokształtu działalności przedsiębiorstw przemysłowych osiagnął przemysł spożywczy w kwocie 234 194,9 mln zł, co stanowiło prawie 20\% całości przychodów przetwórstwa przemysłowego, który wyniósł 111 4687,9 mln zł, potwierdzając to, iż jest istotny dla polskiej gospodarki. Tabela 3. ukazuje ile jedna osoba przeznaczyła na wydatki w 2014 roku.

TABELA 3.

\section{Przeciętne miesięczne wydatki na jedną osobę w 2014 roku (w zł)}

\begin{tabular}{|l|r|}
\hline \multicolumn{1}{|c|}{ Wyszczególnienie } & 1078,74 \\
\hline Ogółem & 1031,62 \\
Towary i usługi konsumpcyjne & 263,34 \\
Żywność i napoje bezalkoholowe & 27,24 \\
Napoje alkoholowe i wyroby tytoniowe & 57,78 \\
Odzież i obuwie & 216,73 \\
Użytkowanie mieszkania lub domu i nośniki energii & 52,76 \\
Wyposażenie mieszkania i prowadzenie gospodarstwa domowego & 53,95 \\
Zdrowie & 98,99 \\
Transport & 54,17 \\
Lączność & 70,13 \\
Rekreacja i kultura & 11,98 \\
Edukacja & 45,09 \\
Restauracje i hotele & 62,51 \\
Pozostałe wydatki na towary i usługi & 24,4 \\
Udział wydatków na żywność i napoje bezalkoholowe w wydatkach ogółem (w \%) & 20,1 \\
\hline Udział wydatków na użytkowanie mieszkania i nośniki energii w wydatkach ogółem (w \%) & \\
\hline
\end{tabular}

Źródło: opracowanie własne na podstawie danych GUS: [http://stat.gov.pl/].

W 2014 roku przeciętne miesięczne wydatki na jedną osobę w złotówkach, na artykuły spożywcze w wydatkach ogółem, wyniosły 25\%, co stanowiło znaczącą ich część. Przemysł spożywczy jest istotny na tle polskiej gospodarki. Społeczeństwo nie może egzystować bez artykułów spożywczych, zatem większość przedsiębiorstw przemysłu spożywczego powinno uwzględniać w swych strategiach zasady zrównoważonego rozwoju, przekształcając się w zrównoważone przedsiębiorstwa produkcyjne generujące zrównoważone produkty w procesach czystej produkcji. 
Zaprezentowane dane wskazują na to, jak ogromne znaczenie dla polskiej gospodarki ma przemysł spożywczy. Wydaje się zatem bezspornie konieczne to, aby wprowadzać do tych przedsiębiorstw długoterminowe strategie, uwzględniające dobro obecnych i przyszłych pokoleń. Poniżej zaprezentowano działania, jakie powinny zostać włączone do strategii przedsiębiorstw produkcyjnych przemysłu spożywczego o charakterze prospołecznym i proekologicznym, zgodnie z zasadami koncepcji zrównoważonego rozwoju.

\section{Działania przyczyniające się do zrównoważonego rozwoju}

Przedsiębiorstwa przemysłu spożywczego, które wcielają koncepcję zrównoważonego rozwoju do swoich strategii, troszczą się o społeczeństwo i środowisko naturalne. $\mathrm{Na}$ ludzkość i środowisko naturalne negatywny wpływ maja: produkcja artykułów spożywczych, ich przetwarzanie przez dostawców i zakłady je produkujące, zużywana do ich produkcji energia i zasoby nieodnawialne, transport, ich utylizowanie oraz recykling. Jednakże istnieje możliwość, aby w całym opisanym łańcuchu wartości zminimalizować negatywny wpływ z prowadzonej działalności produkcyjnej artykułów spożywczych na konsumentów i środowisko przyrodnicze.

Wszystkie oferowane na rynek produkty powinny nabrać cech zrównoważenia. Projektowanie ich uwzględnia ochronę środowiska przyrodniczego. Opracowując produkt, powinno się myśleć przede wszystkim kategoriami cyklu użytkowania środowiskowego. Artykuł produkuje się, respektując zasady ochrony środowiska. Aby sprostać wymaganiom konsumentów, powinno się dostosować swoją działalność do obowiązujących przepisów prawnych, jak również zasad etycznych. Produkt zrównoważony jest: zdrowy, bezpieczny i trwały, a powstaje on w procesie czystej produkcji. Indywidualny kodeks etyczny, znajdujący się w przedsiębiorstwie, jest czymś więcej aniżeli prawnym nakazem respektowania, obwarowanym finansowymi sankcjami. Produkt zrównoważony charakteryzuje wysoka jakość, odpowiedni skład, a jego opakowanie nadaje się do recyklingu bądź jest biodegradowalne.

Produkt spożywczy, który jest zdrowy i bezpieczny dla konsumenta, wyróżnia wysoka jakość. Najwyższa jakość i bezpieczeństwo gwarantuja produktom systemy zarządzania w przedsiębiorstwach, skupiające się na poszczególnych etapach aktywności cyklu życia produktu, począwszy od potrzeb konsumentów, poprzez rozwój produktu, pozyskiwanie surowców, generowanie opakowań, produkcję i dystrybucję, kończąc na rzetelnych badaniach dotyczących analizy i oceny poziomu satysfakcji konsumentów. W celu sprawnego posługiwania się systemami zarządzania jakością produktów przez przedsiębiorstwa, niezbędne jest przestrzeganie: prawa obowiązującego w Unii Europejskiej i Polsce, wewnętrznych regulacji ustanowionych w każdym przedsiębiorstwie, a także Norm Systemu Bezpieczeństwa Żywności ISO 22000:2005. Każde przedsiębiorstwo produkcyjne posiada swoje elementy, będące podstawami systemów zarządzania jakością produktów. Należy w nich dążyć do likwidacji defektów i strat, postępować zgodnie z prawem $i$ indywidualnymi systemami bezpieczeństwa, angażować na każdym etapie tworzenia i produkowania dóbr zrównoważonych pracowników, którzy są wrażliwi 
ekologicznie i społecznie oraz postępować zgodnie z oczekiwaniami nabywców. Konieczne jest również, aby poszczególni partnerzy biznesowi także respektowali te same założenia dotyczące standardów jakości, zgodnie z zasadami zrównoważonego rozwoju.

Wcielając do strategii przedsiębiorstwa zasady zrównoważonego rozwoju, wymagane jest, aby w procesach produkcyjnych ograniczać negatywny wpływ z działalności na środowisko naturalne, wprowadzając długoterminowe planowanie. W tym celu wdraża się system zarządzania ochroną środowiska (Norma ISO 14001 Zarzadzanie Środoniskowe) oraz inwestuje $\mathrm{w}$ te procesy, w wyniku których zmierza się do poprawy w osiagnięciach związanych z ochroną środowiska. Przedsiębiorstwa koncentrują się na tym, by w procesach produkcyjnych minimalizować wykorzystanie energii i chemikaliów zanieczyszczających środowisko.

Rosnąca liczba ludności powoduje zwiększenie popytu na artykuły spożywcze. Zachodza zmiany klimatyczne i dochodzi do kurczenia się zasobów wody zdatnej do picia, której rolnictwo zużywa $70 \%$, przemysł $20 \%$, a gospodarstwa domowe $10 \%$. Wyszczególnione negatywne zjawiska powodują, iż społeczeństwu zaczyna grozić deficyt $\mathrm{w}$ dostępie do wody. Problem ten nie może być ignorowany przez przedsiębiorstwa przemysłu spożywczego, toteż konieczne jest odpowiedzialne gospodarowanie wodą i jej zasobami. Polska pośród 27 krajów Unii uplasowała się na 24. miejscu, gdzie na 1 mieszkańca przypada $1700 \mathrm{~m}^{3}$ wody pitnej, gdyż jej zasoby w Polsce są ograniczone [Eurostat].

Skuteczne zarządzanie zasobami wody w przedsiębiorstwach przemysłu spożywczego jest możliwe dzięki realizowaniu następujących działań:

- zwiększenie efektywności zużycia wody na każdym etapie działalności przedsiębiorstwa poprzez ograniczenie ilości pobranej wody na tonę produktu. Wprowadzając do przedsiębiorstwa projekt „Mapowania wody”, przy wykorzystaniu czujników i mierników, jest możliwe oszacowanie działań, za sprawą których zmniejszy się pobór wody w przeliczeniu na tonę produktu;

- $\quad$ wykorzystując innowacyjne rozwiązania techniczne, konieczne jest coroczne ustalenie poziomu redukcji zużycia wody;

- promowanie działań mogących pomóc oszczędzać wodę;

- $\quad$ wprowadzanie do przedsiębiorstw Normy ISO 14046:2014 (Water footprint Principles, requirements and guidelines), która mierzy ślad wodny wody;

- efektywne gospodarowanie emisją ścieków;

- zachęcanie dostawców do odpowiedzialnego korzystania z wody;

- zwiększanie świadomości społeczeństw i odbiorców na temat ochrony zasobów wody.

Ważne jest zwiększenie możliwości oszczędzania wody w przedsiębiorstwach produkcyjnych przemysłu spożywczego, stosując recykling i jej ponowne zużycie, a także realizować obieg zamknięty. Niektóre przedsiębiorstwa, posiadające przyzakładowe oczyszczalnie ścieków, każdego roku mogą oszczędzać wodę, używając ją do mycia linii produkcyjnej. Ponownie wykorzystuje się wodę z instalacji do produkcji pary wodnej i mycia warzyw, jak również używaną, aby chłodzić urządzenia do mycia urządzeń myjących linię produkcyjną. Jednocześnie można zrealizować projekt, co przyspiesza cykl skraplania wody. 
Przedsiębiorstwa, aby rozwijać się, wcielają do swych strategii koncepcję zrównoważonego rozwoju. Kolejne zakłady produkcyjne i magazyny sa budowane zgodnie z zasadami zrównoważonego projektowania i wznoszenia nowych budynków. Realizowane są one w myśl globalnych standardów dotyczących wpływu na planetę Ziemię.

W procesach logistyki, takich jak transport, oraz podczas podróży służbowych ważne jest, aby ograniczyć ślad węglowy. W tym celu konieczne wydaje się optymalizowanie stopnia wypełnienia dostawczych samochodów ciężarowych. Zastąpienie transportu samochodowego kolejowym wpłynie na obniżenie emisji dwutlenku węgla, toteż nieodzowne jest przeprowadzenie tej zmiany.

Podczas wyjazdów służbowych wykorzystuje się transport lotniczy, który jest emitentem największej ilości dwutlenku węgla. Trzeba podkreślić, iż roczna emisja $\mathrm{CO}_{2}$ przez przemysł lotniczy wynosi tyle, ile emituje go średniej wielkości uprzemysłowiony kraj. Wynosi obecnie 2\% globalnej emisji tego gazu. Jednakże szybko rozwijająca się branża lotnicza może nawet przekroczyć 3\% światowej emisji [http://www.lot.com/pl/pl/]. Aby zminimalizować emisję dwutlenku węgla w tym aspekcie, należy w większym stopniu posługiwać się nowymi technologiami i programami do komunikacji w Internecie. Będzie to alternatywnym rozwiązaniem dla pracowników, którzy utrzymują międzynarodowe kontakty. W przedsiębiorstwach przemysłu spożywczego stosuje się innowacyjne wideokonferencje. Narzędzia do wirtualnej współpracy będzie można wykorzystywać także podczas szkoleń, co pozwoli obniżyć emisję $\mathrm{CO}_{2}$, zmniejszyć koszty, jak również obniży marnowanie wielu godzin pracowników w podróżach służbowych.

Od momentu akcesji Polski do Unii Europejskiej na przedsiębiorcach, oferujących na rynek artykuły opakowaniowe, ciąży formalny, prawny obowiązek odzyskiwania części powstałych w wyniku ich użytkowania i oddania ich do recyklingu. Prawo stanowi, jaką ilość opakowań i które z nich odzyskuje się. Przedsiębiorcy zlecają odzysk specjalistycznym firmom tym zajmującym się lub wykonują to samodzielnie. Często aluminium jest wykorzystywane do produkcji opakowań żywności, co gwarantuje wysoką jakość przetrzymywanych produktów i ich bezpieczeństwo. Aluminium można zastąpić folią lub folią metalizowaną, gdyż odzysk i recykling aluminium stanowi duże wyzwanie.

\section{Podsumowanie}

Pod względem ilości podmiotów gospodarczych w Polsce, przemysł spożywczy obejmuje około $20 \%$ całego przetwórstwa przemysłowego. Wprowadzanie innowacji w przedsiębiorstwach produkcyjnych przemysłu spożywczego sprzyja wdrażaniu zrównoważonego rozwoju do strategii przedsiębiorstw. Produkcja szczególnie szkodzi tak człowiekowi, jak i środowisku naturalnemu, dlatego ważne jest, aby nabierała ona coraz więcej cech zrównoważenia.

Wielkość przemysłu spożywczego i szkodliwość procesów produkcyjnych, jakie on generuje, powoduje konieczność wdrażania zasad zrównoważonego rozwoju przez przedsiębiorców do ich strategii. Przedstawione w artykule działania, który mogą być zrealizowane przez przedsiębiorców, obrazuja, jak powinno wygląać prowadzenie zrównoważonej działalności biznesowej w sektorze spożywczym, aby w jak najwyższym stop- 
niu chronić społeczeństwo i środowisko naturalne. Działalność przemysłowa z ekspansywnej powinna stopniowo zacząć zmieniać się w zrównoważoną. Jedynie dzięki tej koncepcji może stać się realne zahamowanie degradacji przyrody oraz kurczenia się, i tak już ubogich, naturalnych zasobów nieodnawialnych.

Sformułowany na wstępie artykułu cel został zrealizowany, gdyż dokonano przeglądu działań, jakie powinny być podejmowane przez przedsiębiorców branży spożywczej, wynikających z wcielania do ich strategii zasad koncepcji zrównoważonego rozwoju. Realizowanie ich przyczyni się do zmniejszenia negatywnego wpływu z prowadzonej działalności produkcyjnej na planetę, co pozwoli żyć społeczeństwu w czystym środowisku przyrodniczym. Wprowadzane do przedsiębiorstw innowacyjne działania, będące konsekwencją wdrażania do ich strategii zasad zrównoważonego rozwoju, służą poprawie jakości życia obecnych i przyszłych społeczeństw. Przedsiębiorstwa te cieszą się bardzo dużą ilością konsumentów, skutkiem czego działalność ta wyrządza wiele szkód środowisku naturalnemu. Cel artykułu został osiagnięty dzięki poznanym odpowiedziom na postawione problemy badawcze.

Poprawie jakości życia społeczeństw w czystym środowisku naturalnym istotnie służą starania zmierzające do tego, aby wszystkie przedsiębiorstwa produkcyjne branży spożywczej realizowały zaprezentowane działania związane ze zrównoważonym rozwojem. Duże znaczenie ma promowanie, propagowanie i edukacja z zakresu zrównoważonego rozwoju zarówno producentów realizujących działalność biznesową, jak i społeczeństwa, by nabywali oni jedynie zrównoważone artykuły, powstałe w procesie czystej produkcji. Współpraca przedsiębiorców, władz, mediów i konsumentów w tym obszarze spowoduje, iż realizowanie zasad zrównoważonego rozwoju ma szansę odnieść sukces.

\section{Literatura}

Adamczyk J., 2001, Koncepija zrównoważonego rozwoju w zarzqdzaniu przedsiębiorstwem, Wydawnictwo Akademii Ekonomicznej, Kraków.

Agenda 21 w Polsce, 1997, Sprawozdanie z realizacji w latach 1992-1996, Ministerstwo Ochrony Środowiska, Zasobów Naturalnych i Leśnictwa, Warszawa.

Brzustewicz P., 2013, Zarzadzanie tańcuchem dostaw a cykl sycia produktu, „Marketing i Rynek", nr 12.

Climate Change: Global Risks, Challenges and Decisions, 2011, K. Richardson, W. Steffen, D. Liverman (eds.), Cambridge University Press, Cambridge, UK.

Creating shared value, 2011, M. Porter, M. Kramer (eds.), Harvard Business Review, no. 1.

Dyrektywa 2000/13/WE Parlamentu Europejskiego i Rady z.dnia 20 marca 2000 roku w sprawie zbliżenia ustawodawstw panstw członkowskich z. zakeresu etykietowania, prezentacji i reklamy srodków spożywczych, Dz. U. L 109 z 6.5.2000.

Eurostat, http://ec.europa.eu/eurostat (data wejścia: 15.04.2017).

http://stat.gov.pl/ (data wejścia: 15.04.2017).

http://www.lot.com/pl/pl/ (data wejścia: 15.04.2017).

Kowalczyk A., 2010, Turystyka zrównoważona, Wydawnictwo Naukowe PWN, Warszawa. 
Kurzak A., 2014, Analiza džiatan przedsiębiorstw produkcyjnych realizujacych zasady zrównoważonego zarzadzania, [w:] Wspótczesne problemy zarzadzania w podmiotach gospodarczych i publicznych, D. Wielgórka (red.), Wydawnictwo Politechniki Częstochowskiej, Częstochowa.

Marketing 3.0, 2010, P. Kotler, H. Kartajaya, I. Setiawan (red.), Wydawnictwo MT Biznes, Warszawa.

National Footprint Accounts, 2016 Edition, Global Footprint Network, www.footprintnetwork.org/en/index.php/GFN/blog/national_footprint_accounts _2016_carbon_makes_up_60_of_worlds_footprint (data wejścia: 15.04.2017).

Our Common Future, 1987, Report of the World Commission on Environment and Development, Oxford University Press, Oxford, 11 December.

Pabian A., 2013, Driatalność promocyjna w koncepgï sustainability, „Marketing i Rynek”, nr 8.

Protokót z Kioto do Ramowvej Konwencii Narodón Zjednoczonych w sprawie zmian klimatu, Sporządzony w Kioto 11 grudnia 1997 roku, Dz. U. 2005, Nr 203, poz. 1684.

Rockström J., Steffen W., Noone K., Persson A., Chapin F.S., Lambin E., Lenton T.M., Scheffer M., Folke C., Schellnhuber H., Nykvist B., de Wit C.A., Hughes T., Van der Leeuw S., Rodhe H., Sörlin S., Snyder P.K., Costanza R., Svedin U., Falkenmark M., Karlberg L., Corell R.W., Fabry V.J., Hansen J., Walker B., Liverman D., Richardson K., Crutzen P., Foley J., 2009, Planetary boundaries: Exploring the safe operating space for humanity, "Ecology and Society", 14, no. 2, art. 32.

Rogall H., 2010, Ekonomia ₹równoważonego rozwoju, Wydawnictwo Zysk i S-ka, Poznań. Sustainability w biznesie, csyli przedsiebiorstwo prayszłości. Zmiany paradygmatów i koncepcii zarzqadzania, 2010, W.M. Grudzewski, I.K. Hejduk, A. Sankowska, A. Wańtuchowicz (red.), Wydawnictwo Poltext, Warszawa.

Ustawa o bezpieczenśntwie śywności i šynienia z 2006 roku, Dz. U. 2006, Nr 171, poz. 1225. 